\title{
Corrective Feedback that "O" Level Students Get from their English Composition Teachers in Bulawayo: A Qualitative Approach
}

\author{
Stella Muchemwa ${ }^{1} \&$ Vencie Allida $^{2}$ \\ ${ }^{1}$ Solusi University, Languages and Communication Department, Zimbabwe \\ ${ }^{2}$ University of Eastern Africa, Education Department, Baraton, Kenya \\ Correspondence: Stella Muchemwa, Solusi University, Zimbabwe. \\ Email: muchemwas@solusi.ac.zw
}

Received: October 14, 2018

Accepted: January 20, 2019

Online Published: March 1, 2019

doi: 10.23918/ijsses.v5i3p142

\begin{abstract}
Teacher's corrective feedback is essential in composition writing for students. This qualitative study used a convenient sample of seven " $O$ " Level (form four) English Language students from one conveniently chosen school in Bulawayo, Zimbabwe. Researchers collected data through interviews of the seven informants and composition exercise books content analysis for all the students in the form four classes of the chosen school. The collected data was organized, coded and analyzed according to the themes that emerged. Findings showed that on Feed Up, students got adequate teachers' explanations on composition goals, expectations, instructions and guidelines. The teachers also prepared students to write compositions psychologically. On Feed Back, students got corrected work, meaningful comments and marks from their teachers. Teachers thoroughly marked students' composition books focusing on English "O" Level syllabus requirements. In their marking, teachers used correction codes to indicate errors, however, some students could not understand the code meanings since they were not given to them. On Feed Forward, composition teachers used the information they got from the students' performance for planning purposes, for instance, due to students' low performance, teachers thoroughly marked students' compositions; they made students' consultation time available, giving weekend and holiday composition exercises as well as encouraging students to write corrections. However, the teacher did not emphasize other aspects, for instance, the total composition marks as part of composition expectations and the teacher hardly conversed with the students. There was also a problem of insufficient feedback resources from their teachers. The study recommended that sufficient feedback resources should be supplied to the composition teachers and students. All composition teachers should explain composition mark allocation to the students whenever they give them composition work. Again, whenever composition teachers use correction codes, elaborations should accompany those codes.
\end{abstract}

Keywords: Zimbabwe, Corrective Feedback, Composition Wring, “O” Level

\section{Background Information}

Composition writing is a real task that calls for mutual cooperation between the teacher and the learner. To this effect, the English composition students benefit a lot from their teachers' corrective feedback. This corrective feedback can be divided into three categories: Feed Up, Feed Back and Feed Forward. Feed Up, in composition writing, is closely linked to goal clarification by the teacher. It shows students the direction in composition writing. Hattie and Timperley (2007) argued that Feed Up answers the question: Where am I going? This question is asked to self by an English composition student and is largely answered by the teacher's guidance. 
Feed Back is related to Feed Up and, in this context, it refers to teacher's response to students' written compositions so that the students' question, How am I going? is answered (Hattie \& Timperley, 2007). This is also in line with what Nielsen (2015) found that teachers use Feed Back during the learning process to communicate to students. Finally, Feed Forward answers the question, Where to next? It is a question closely linked to the use of assessment data to plan for the future. In line with Feed Forward, Dreher (2016) emphasized on focusing on improving future performance rather than spending too much time discussing the past that cannot be changed. This means using past actions to inform the crafting of new strategies for future improvement.

\section{Reviewed Literature}

Significant literature is available on teacher corrective feedback and its impact on second language learning. McCarthy (2016) defines teacher corrective feedback as help from the teacher which can make students positively change their performance. However, Wiggins (2014) was quick to realize that feedback can be unhelpful when learners have not been provided with a model answer against which to compare their work. Model answers, as part of teacher's corrective feedback, are necessary because English composition students have challenges especially in countries like Zimbabwe where English is taught as a second language (Nabiryo, 2011; Oyedele \& Chikwature, 2016). Characteristics of teacher corrective feedback include: specific and focused (Saaris, 2016); directional and straightforwardness (Farrokhi \& Sattarpour as cited in Kang \& Han, 2015); informative (Saaris, 2016; Lee 201) timely (Reynolds, 2013) and detailed (Nielsen, 2015).

What scholars realised is that giving effective feedback is not easy (Dreher, 2016). This has been proved by Çagla (2016) whose study showed that the teachers were not making their expectations from students in a clear way. Also, the feedback process is time consuming. Lee (2011); Bruno and Santos (2010); Parr \& Timperley (2010) as well as Brown (2012) observed that language teachers spend much of their time marking and providing corrective feedback on students' writing.

Despite the difficulties that are encountered in composition writing, standards should be maintained. The Zimbabwe General Certificate in Education (ZGCE) "O" Level English syllabus, 2013-2017 gives composition writing stipulations and these include:

- Write a continuous narrative, an argument and a piece of descriptive or informative writing such as that of a process, of a character, a scene or of an event;

- Organize their work satisfactorily into paragraphs and show a sense of cohesion /coherence within paragraphs;

- Show an awareness of discourse markers ...; write with grammatical accuracy, spell accurately and punctuate their work correctly....

When composition teachers mark students' work, providing numerical marks and comments, they are guided by such syllabus stipulations. Elliott et al. (2016) argued that marking can provide important feedback to pupils and help teachers identify pupils' misunderstandings. Chen, Nassaji and Liu (2016) in a study showed that students held a strong preference for such extended comments on both content and grammar of their written work. Composition marking is usually associated with the use of correction 
codes, for instance, $s p$ for a wrong spelling and $w w$ for a wrong word. A study by Alvira (2016) on the composition teachers' use of correction codes showed that the use of coded written feedback was widely accepted by students and was yielding positive results in the improvement of their writing skills at paragraph level.

Apart from the written corrective feedback, oral corrective feedback is also helpful to English composition writers (Mahmoodi \& Rajabi, 2014; Küçükali, 2017; Catapano, 2017). It is not only the student who benefits from the teacher feedback but also vice- versa. The current Socio-constructivist Model of learning views feedback as dialogue where the teacher is no longer the sole provider of feedback but also the students become important additional feedback sources (Carless, 2015). That giveand-take process between the teacher and the student can eventually create and enhances student-teacher relationship and student improvement (Crimmins et al., 2016).

\section{Statement of the Problem}

Corrective feedback is meant to correct students' composition writing. However, "O" Level English in Zimbabwe still experiences low performance in composition writing despite composition teachers' corrective feedback (Three-mob.com. 2013; Gwata, 2017). The details of the nature of the teachers' corrective feedback, at least in Bulawayo, Zimbabwe, are not known. This study therefore focused on finding out the characteristics of the corrective feedback that "O" Level students get from their English composition teachers in Bulawayo so that informed decisions can be made for composition writing improvements in Zimbabwe.

\section{Research Question}

1. What types of corrective feedback do "O" Level students get from their composition teachers in terms of:

a) Feed Up

b) Feed Back

c) Feed Forward?

\section{Research Methodology}

This qualitative study used a convenient sample of seven "O" Level (form four) English Language students from one school conveniently chosen in Bulawayo where students were steamed according to academic ability, that is, Class A, for the best students; Class B for the average students and Class C for the academically struggling students. Two students were chosen from Class A; three intermediate performers from class B and two less privileged academic performers from Class C, as informants. The researchers did composition exercise books content analysis for all the students in the form three classes. On the agreed date and time, the researcher, with an assistant researcher who also acted as a photographer approached the intended school. The two conducted in-depth interviews to seven "O" Level students, in the HOD's office, one at a time, from that one school in Bulawayo to find out their responses to composition teachers' written corrective feedback. 
During interviews, the informants brought their composition exercise books for content analysis. The school English Head of Department (HOD) also brought the rest of the B class composition exercise books and some of the $\mathrm{A}$ and $\mathrm{C}$ class composition exercise books making a total of 81composition exercise books. After the interviews, the researcher, the assistant researcher and the English HOD sat; the researchers and the HOD carried out a brief content analysis of the composition exercise books concentrating on the major feedback aspect evidenced in the students' books. The assistant researcher was taking photographs of composition extracts per researcher's instructions. During interviews, the informants brought their composition exercise books for content analysis. The HOD also brought the rest of the B, A and C class composition exercise books. After the interviews, the researcher, the assistant researcher and the English HOD carried out a brief content analysis of the composition exercise books concentrating on the major feedback aspect evidenced in the students' books. The assistant researcher was taking photographs of composition extracts per researcher's instructions. Data collected from interviews and content analysis was then organized, coded and analyzed according to the themes that emerged.

\section{Research Findings and Discussion}

Research Question One: What types of written corrective feedback do "O" Level students get from their composition teachers in terms of Feed Up, Feed Back and Feed Forward?

\subsection{Feed Up}

The researchers collected data through students' interview responses and content analysis of the students' composition exercise books. From the interviews, the informants showed that they were happy with their teacher's explanation on the long-term composition goal: to be able to write a standard composition according to English language "O" Level syllabus demands. The informants also said that their teachers clearly explained to them the expectations for every composition that they wrote. This help from the teacher can make students positively change in their performance as McCarthy (2016) put it. One informant from the $\mathrm{C}$ class gave the following details with satisfaction:

Excerpt 1: Our teacher gives us a topic then guidelines on how to approach that topic. Sometimes she reads a story related to that topic and further explains her expectations from us in our compositions in relation to the story read. Another student from the same $\mathrm{C}$ class said that their teacher sometimes gave them points to expand when writing the composition. Content analysis of the informant composition exercise book confirmed this as shown below; the teacher's written comments below (last sentence on the picture) reads: Write using given points... an indicator that the teacher provided students with some points to expand and work on. 


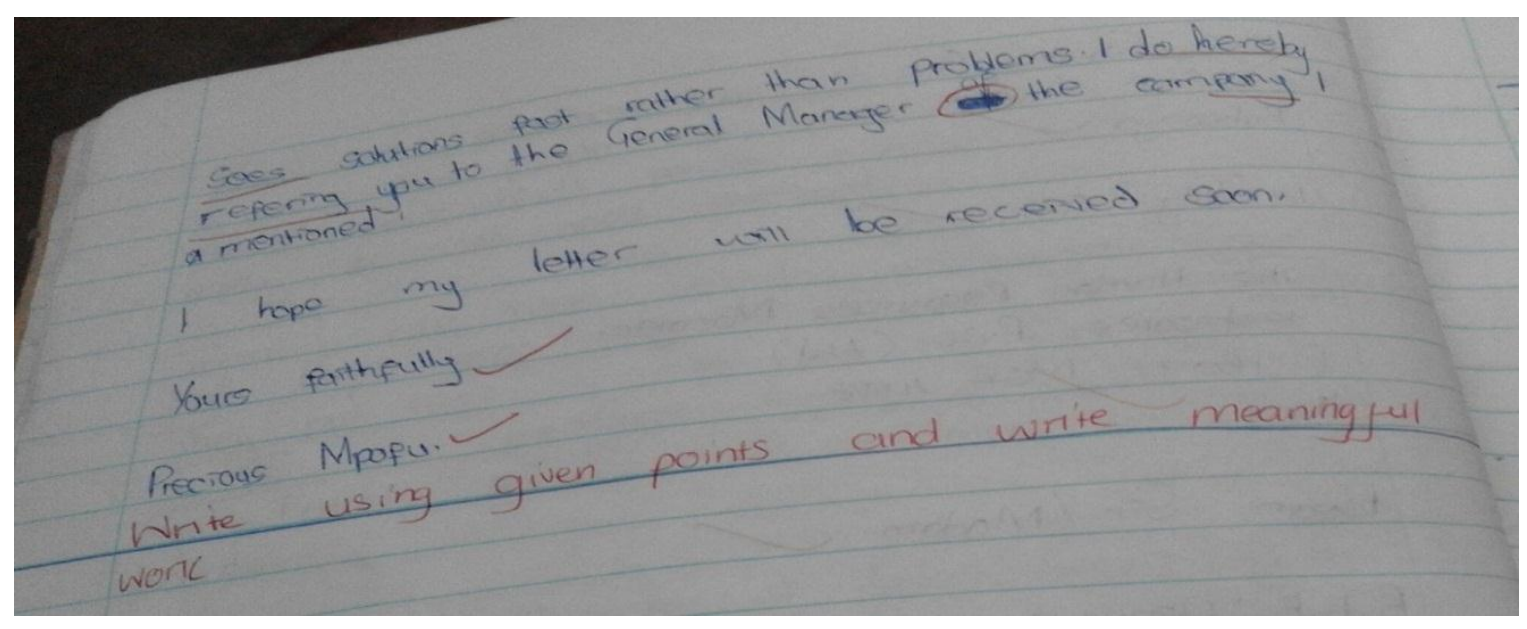

Some informant said that their teacher gave them vocabulary words to use when writing compositions. The composition teacher also encouraged them to consult other teachers (English teachers and nonEnglish teachers for techniques and content, respectively) for information on given topics. Again, the teacher also read good compositions in class, specifically in the $\mathrm{C}$ class for other students to see how it should be done; one $\mathrm{C}$ class informant positively said:

Excerpt 2: Our teacher reads good compositions from colleagues so that we know her (teacher) expectations. We learn from others. This is in line with Wiggins (2014) who realized that feedback can be unhelpful when learners have not been provided with a model answer against which to compare their work. In the A and B class, the informants said that the teacher never read model answers. This shows that the teacher gave extra help to the students in the $\mathrm{C}$ class as compared to those in the A and B class. This is quite in order because the $\mathrm{C}$ class students really struggle with English; during the interview, the two informants from the $\mathrm{C}$ class could hardly speak in English despite my encouragement for them to do so. The researcher ended up allowing them to talk in vernacular whenever necessary; otherwise she was going to miss a lot of information from them.

The students' composition work, marks and teacher's written comments also confirmed their composition writing challenges. This finding is similar to those by Nabiryo (2011) and Oyedele and Chikwature (2016) in Zimbabwe who also found that few learners were equipped with writing skills. The following extract from the other $\mathrm{C}$ class informant. 


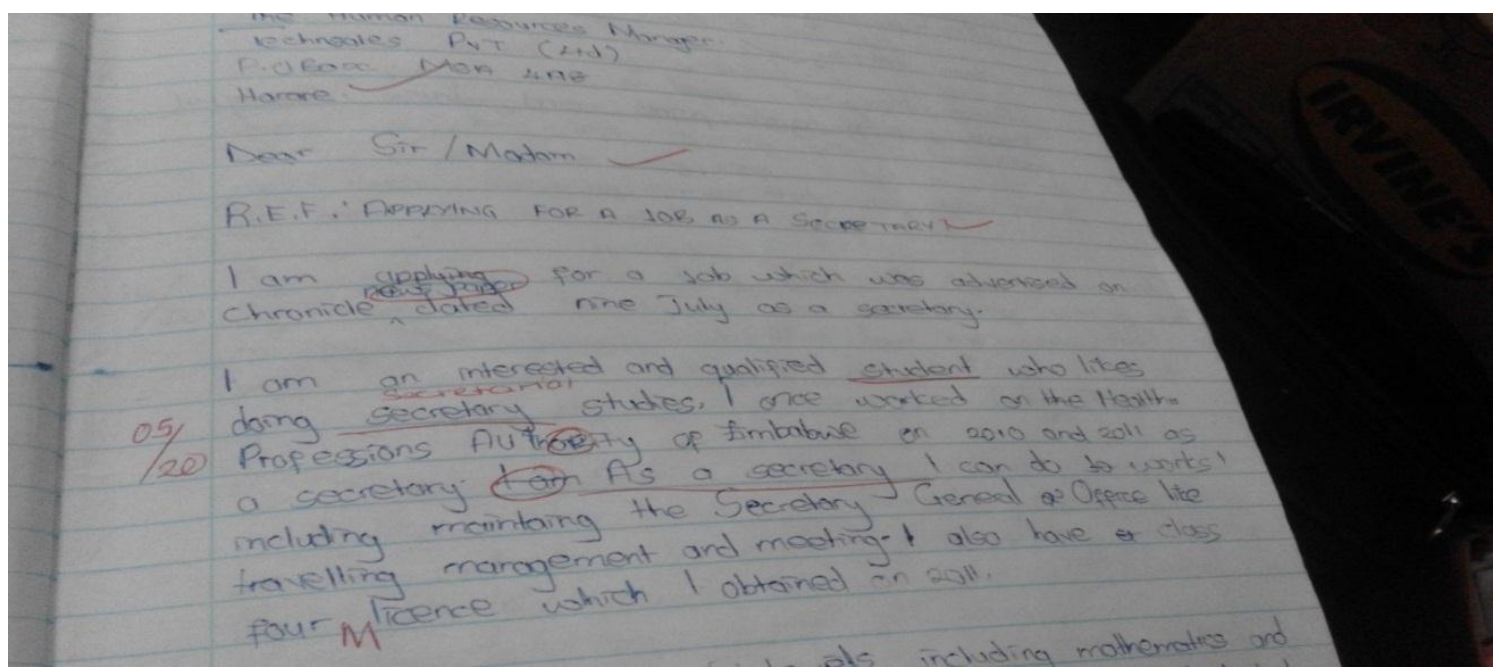

In the extract above, there are some errors that include a wrong preposition, on (though not indicated by the teacher). In line two there is an unclear phrase which is curetted. The second paragraph has wrong words, for instance, the phrase, qualified student instead of qualified personnel and secretary studies instead of secretarial studies in line one and two while in line three there is wrong capitalization: AuthoRity instead of Authority. The rest of the sentences have numerous errors indicated by the teacher's lines, a circle and a caret for omissions. This short composition extract shows errors of all kinds, including spelling errors, grammar mistakes and omissions, which made the teacher take a decision of awarding the student a mark of 5 out of 20, a mark far below half of the total marks. This indicates very low level of performance in composition writing by the $\mathrm{C}$ class students; the other composition exercise books for the students in the same class showed the same trend of marks as revealed by content analysis. On the other hand, the A and the B class students seemed to understand teacher's instruction, that is, those given in the past (probably when the students were in form three) as well those given regularly whenever a composition assignment is given. An informant from the A class has to jovially say the following:

Excerpt 3: She (the teacher) explains in detail the type of composition to be written. She also explains her expectations on that particular composition. Another informant from the A class said that apart from the teacher's instructions soon before composition writing, they know most of the expectations since form three. Informants from the A and B class knew even the total marks for the composition given to them, contrary to the $\mathrm{C}$ class students who said that they were not sure of the total marks of the compositions that there were asked to write. One informant from the C class sadly said:

Excerpt 4: We only come to know the total marks of the composition when we receive our composition exercise books from marking. At times the compositions are marked out of 20 and at other times out of 30; I don't know the difference. The other informant from the same $\mathrm{C}$ class disappointedly said:

Excerpt 5: We are not told of the composition's total marks. The total marks also fluctuate. We only see the total marks when we receive our marked composition books. Analysis of the students' composition exercise books showed that there were basically two types of compositions that the students wrote: free 
and guided compositions. The free composition is long and marked out of 30 while the guided composition is generally short and is marked out of 20. The Zimbabwe General Certificate in Education (ZGCE) "O" Level English syllabus, 2013-2017 showed that the free composition should have 350-450 words (which is about two pages depending on someone's handwriting) whilst the guided composition, although not specified in terms of words, can be slightly shorter than the free composition as indicated by relatively less total marks 20 . These two composition types confused the $\mathrm{C}$ class students for they could not differentiate one from the other. Contrary to the $\mathrm{C}$ class informants, those from the A and B classes could differentiate a guided composition from a free composition, hence they knew the total marks for each and every composition they were asked to write. One informant said:

Excerpt 6: We already know that the free composition is out of 30 while the guided composition is out of 20. What can only surprise me is my real mark, not the total mark. On answering the question on whether they followed teacher's guidelines or not, they all said that they tried by all mean to abide by the teacher's instructions. One informant from the A class confidently said:

Excerpt 7: I follow closely my teacher's expectations, requirements and guidance so that I get high marks. It is also part of my preparations for the final "O" Level examination that I will write at the end of this year. Although some students could not understand some teacher expectations, both students' interviews and content analysis of composition exercise books show that the teacher put effort in making students understand the composition writing expectations. When considering these findings, what Dreher (2016) highlighted that giving written corrective feedback can be a difficult process is proved right. These findings where the teacher puts effort in making the composition writing goal clear is contrary to those by Çagla (2016) whose study showed that the teachers were not making clear their expectations to students. Another important aspect of Feed Up that the students interviews revealed is that the teacher prepared the students to write the compositions psychologically by informing them when they were to write one and academically by providing the necessary materials. One informant from the C class happily said:

Excerpt 8: We are always told in advance when we would write a composition. This gives us time to be prepared for the task. The other one from the B class confidently remarked:

Excerpt 9: We are given ample time to think on a topic. It was two days to think on a topic when we were in form three. This year, when we are now in form four, the period has been reduced to one day.

When researcher asked why the time has been reduced, the informant wasn't sure but ascribed the change to the demand and increased frequency of composition work in form four. She said:

Excerpt 10: She is preparing us for the final examinations. We will sit for them at the end of this year. Students also prepared themselves to write compositions on their own, though through teacher's direct and indirect influence. Students read prescribed and non-prescribed books for information. One informant from the B class proudly said: 
Excerpt 11: I read many novels; it becomes an advantage when it comes to composition writing for I borrow a lot from what I read from the novels. She went on to say:

Excerpt 12: I borrow storylines from the novels. I also get expressions and vocabulary that I can use in my own compositions. This shows that both teacher and students' efforts make the students prepared to write compositions making it easier for students to write the compositions. One informant from the A class confidently said:

Excerpt 13: I retrieve information stored in my mind; there and there I can think of a story.

\subsection{Feed Back}

Reviewing of students' composition exercise books showed that students usually wrote compositions after every two weeks (as shown by dates) and these compositions were marked and returned to their owners. Students got corrected work, comments and marks as Feed Back to their composition writing. Respondents also confirmed these findings.

Elliott et al. (2016) said that marking can provide important feedback to pupils and help teachers identify pupils' misunderstandings. When addressing the question on teacher's focus when marking students' composition exercise books, all the informants agreed on their responses; what they said their teacher focused on when marking was confirmed by composition exercise books content analysis. These are: grammar, spellings, language, vocabulary, punctuation, paragraphing, monotony, sequence of events, handwriting, composition length and the subject matter of the paragraphs as well as the whole composition. Similarly, Kang and Han (2015) found that teachers spend a great deal of time providing various kinds of corrections, for instance, grammar and spelling. Also, Aoskoz (2017) found that teachers focused on linguistic proficiency including command over grammar, syntax and vocabulary.

Teacher's written comments such as: Improve your spellings and grammar; This is too short for your level; Use varied vocabulary; Your handwriting is illegible and it needs to be improved, were among the common comments in the students' composition exercise books. These aspects are the same highlighted in the Zimbabwe General Certificate in Education (ZGCE) "O” Level English syllabus, 2013-2017. Chen, Nassaji and Liu (2016) showed that students held a strong preference for such extended comments on both content and grammar of their written work. 
When considering the teacher's marking, all the informants said that their teacher was a thorough marker. One of them said that the composition teacher highlighted all the errors that he has made while the other informants echoed that their teacher corrected most of the errors. The researcher confirmed that the teacher indicated many errors in the informants' composition exercise books. This finding is similar to those by (Lee 2011; Bruno \& Santos, 2010; Parr \& Timperley, 2010; Brown, 2012) who observed that language teachers spend much of their time marking and providing corrective feedback on students' writing. The teacher's thorough marking was shown in the students' composition exercise books. The marking was done in a variety of ways as shown on the extract below. In line one, the student has written the word you omitting the letter $r$ which the teacher inserted during her marking; this is explicit error correction.

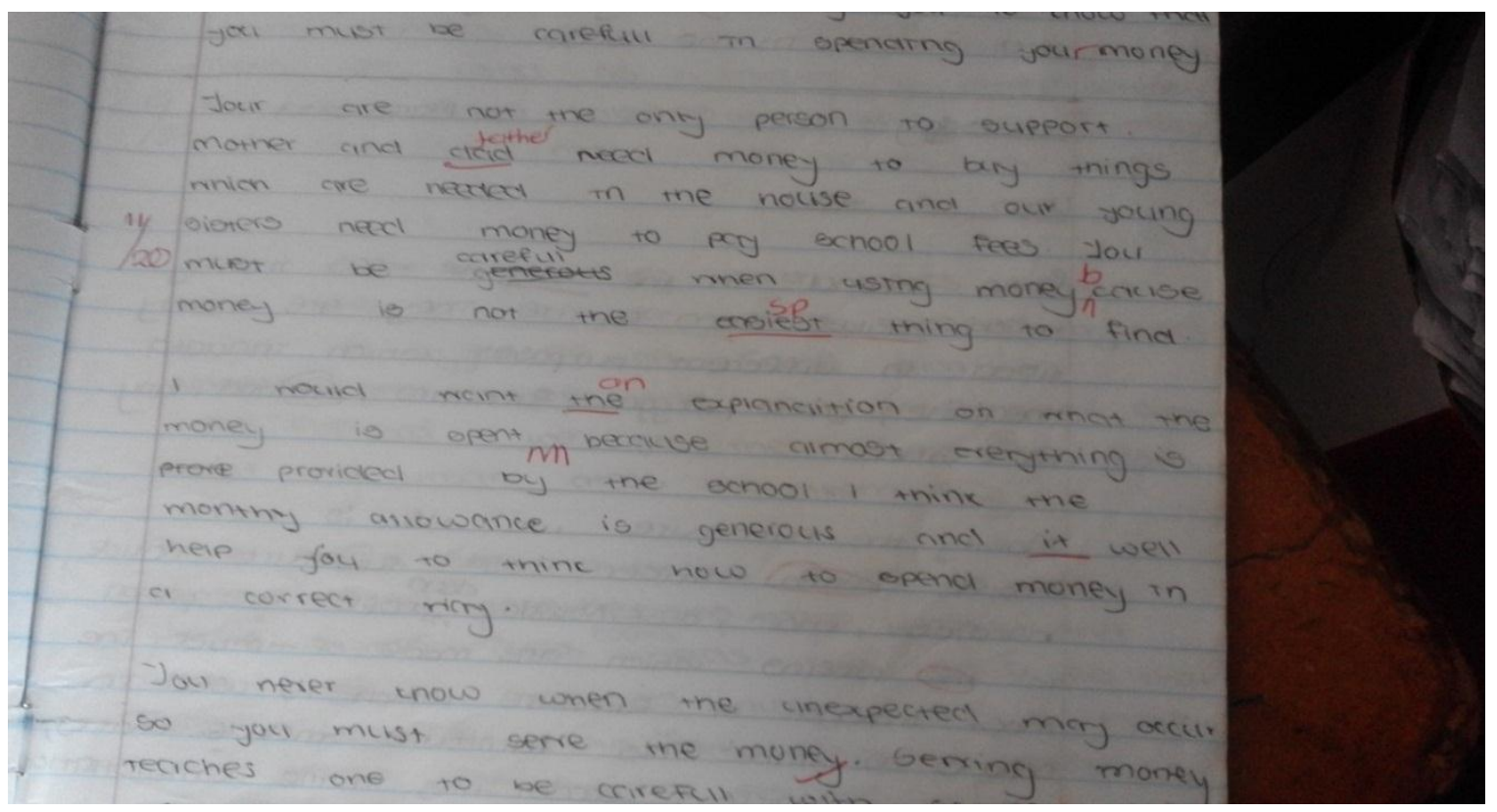

In line three above, the student puts a wrong word, dad which the teacher underlines and wrote the correct word, father above the wrong one; this is also explicit error correction accompanied by error feedback. In line six, the students made an omission which the teacher double indicated by a caret (which is a correction code) and the addition of the missing letter: still another explicit error correction and error feedback. Line seven has a spelling mistake which the teacher highlighted by underlining and putting the code for wrong spelling, sp, above it while line nine has a wrong article the instead of the article an which the teacher inserted and underlined the wrong one; this is explicit correction. Line nine has an omission highlighted by carets (a correction code) and line eleven has a wrong word which is underlined; this is error indication. Finally, there is a tick (a correction code) on paragraph four which indicates that the information is well written and correct as shown on the extract above. The analysis above shows that the common teacher error indication was explicit error correction which is also termed as positive evidence by Shintani (2014). The teacher also used coding and error indication which is negative evidence in Shintani (2014) terms. The use of correction codes that I observed in the informants' composition exercise books was supported by Alvira (2016) who, in a study, realized that the use of coded, written feedback was widely accepted by students and was yielding positive results in 
the improvement of their writing skills at paragraph level. Also, Faqeih (2015) realized that learners' were happy with teacher error correction. For further feedback in the students' composition exercise books classification, the researcher realized that the explicit corrections and error indications elaborated above are in line with Al-Jarrah (2016) first part of premises number one, that is, error correction. The teacher's through marking is also revealed by teacher's comments which occupy several positions in the compositions. There can be at the beginning of a composition as one informant said:

Excerpt 14: My teacher puts comments everywhere in the composition. When the introduction is either good or bad, she puts a comment to that effect. Content analysis confirmed the informant's utterance as shown on the extract below. There is a crossing line on the first sentence and the comment: Follow instructions to show that all is not well and the student needs to be abided by given instructions.

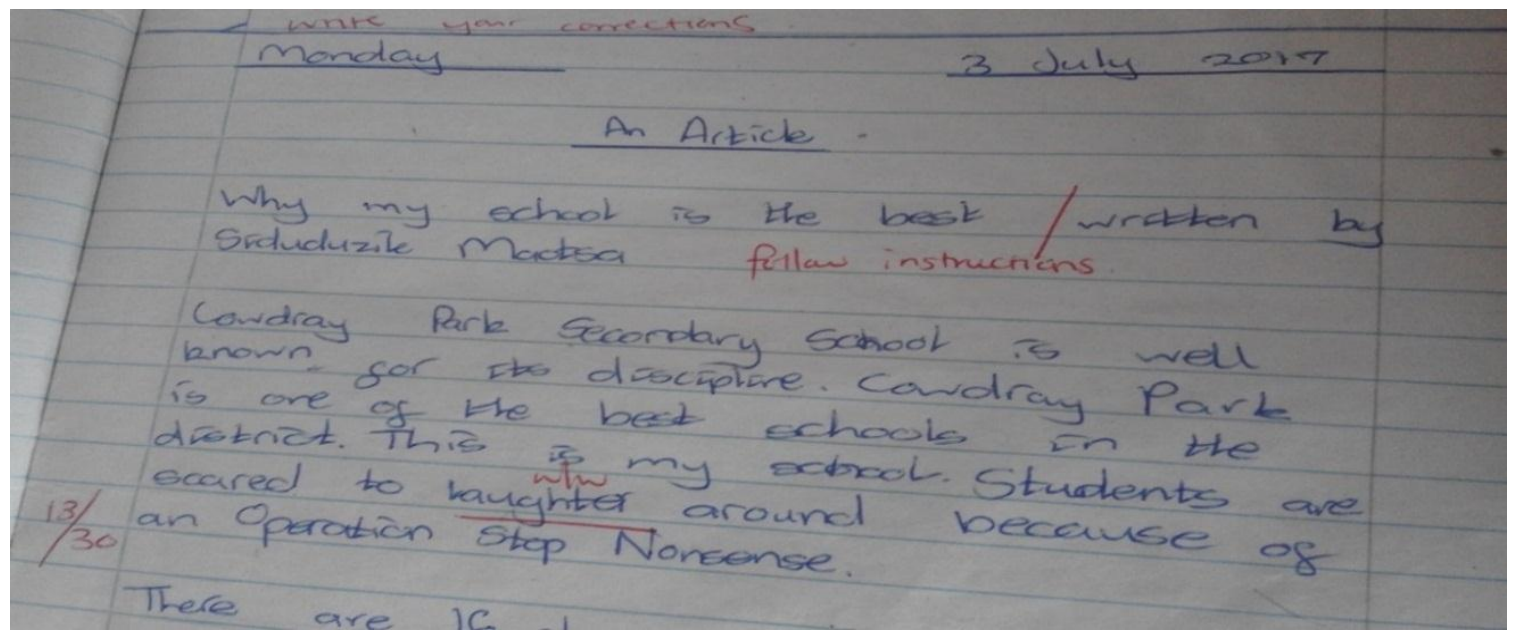

Teacher's seriousness in marking is also revealed by teacher's comments right inside the students' compositions. Such comments usually instruct students on what has been missed, what should have been done and what has been done well, for instance, Use rhetoric questions and not direct questions. This is similar to Catapano (2017) who wrote of margin comments where teacher often squeeze feedback into the margins of student work for targeting specific portions of their work.

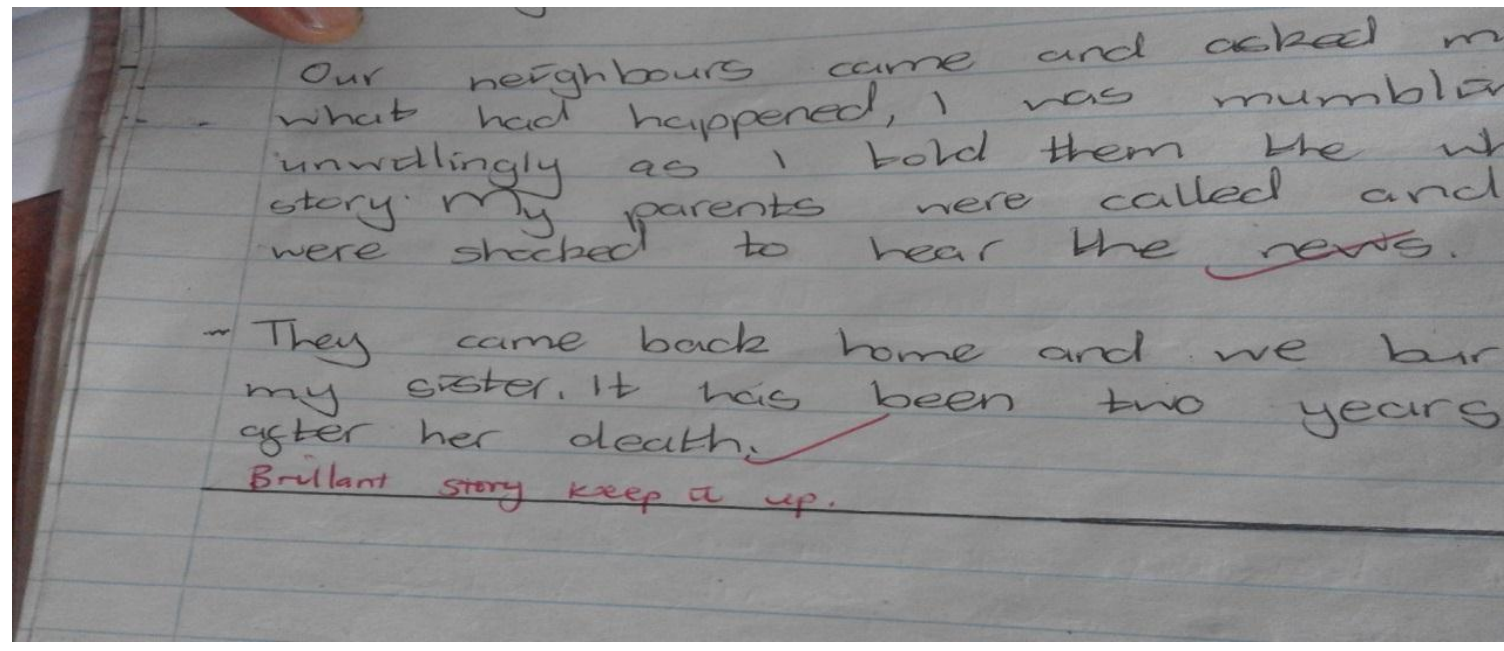


Teacher's comment could also be placed at the end of the composition as an overall comment to the whole composition indicating the student's performance. The overall comment can either be long or short depending on what the teacher needs to communicate as one informant rightfully put it. The following comment is short, clear and positive and it reads: Brilliant story keep it up, an indicator that the composition has been written well.

The short and clear end comment that the composition teacher gave seems as if the teacher responded to Saaris (2016) who argued that non-specific feedback falls far behind feedback that is specific and focused. Teacher's comments were also characterized by being direct (and not in general) usually addressing a problem at hand or an individual addressed by name. Such direct and straightforward comments were recommended by Farrokhi and Sattarpour in Kang and Han (2015) who found superior effects for focused feedback over un-focused feedback. This has also an impact on the student who realizes that the teacher knows herlhim and cares for herhhim as a student. One informant said that she felt recognized and valued as a student when the teacher's comment addressed her by name. Some teacher's comments were detailed, elaborate and exhaustive as shown below:

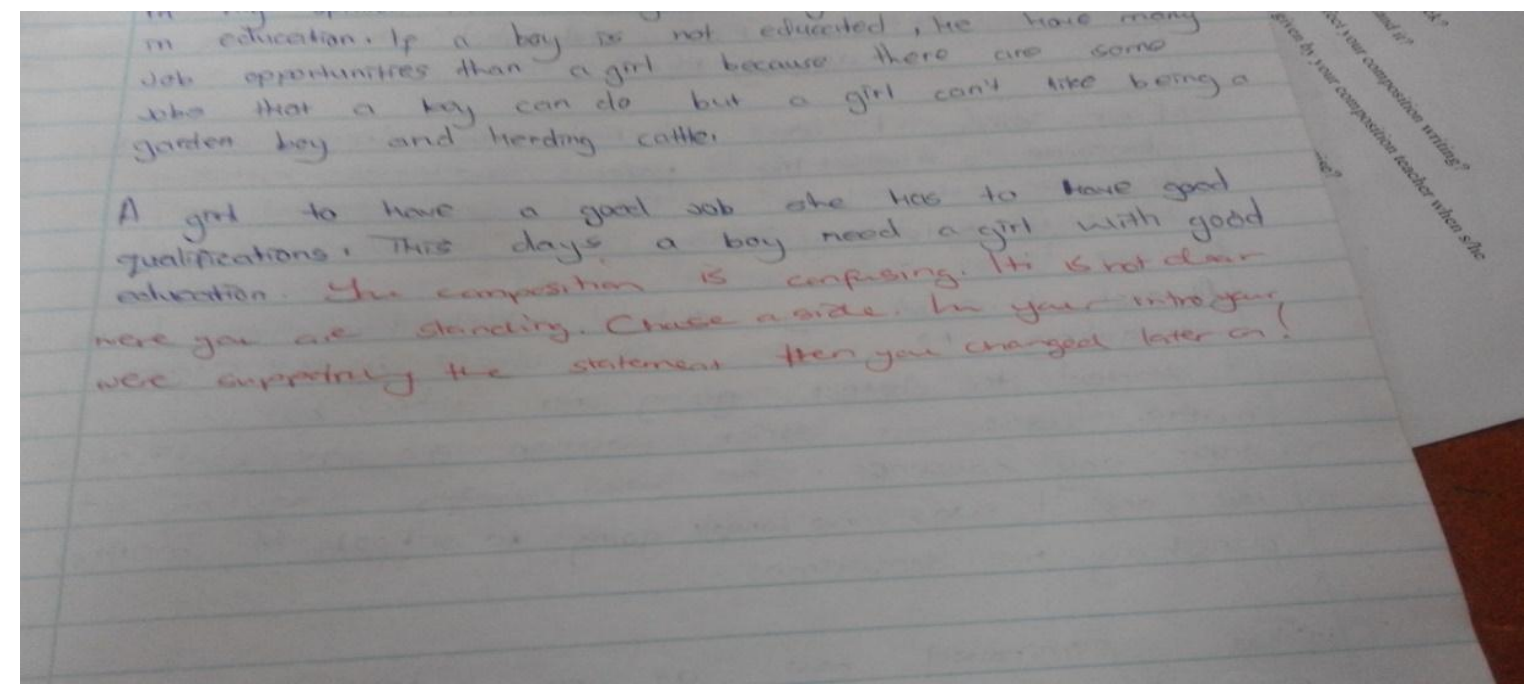

The comment reads: Your composition is confusing. It is not clear where you are standing. Choose a side. In your intro you were supporting the statement then you changed later on. Such informative comments are likely to be very helpful to students as Lee (2011) commented that students value and want teachers to give them feedback on their writing. Also, Nielsen (2015) found out that many students prefer detailed corrective positive feedback which guides them in the revision process. In response to the question on how much time did the informants spend reading teacher's comments when receiving their composition exercise books from marking, most of the informants generally said that they spend some time, without specifying the exact time taken. However, one student from the $\mathrm{C}$ class said that she did not read teacher's comments at all. She innocently said: 
Excerpt 15: I don't read the comments. I concentrate on my teacher's marks only. This means that teachers should not take for granted that students read their comments. They should therefore give students time in class to reflect on written comments in class. When the researcher asked the informant why she never read the comments, she said that she thought only marks mattered. Students also got Feed Back from their composition teacher through marks. Content analysis of students composition exercise books made the researcher realized that there was a strong link between the marks that the students got and the written comments that they received from their teacher. Marks ranges from $19 \backslash 30$ and 14\20 down to $8 \backslash 30$ and $4 \backslash 20$ for free composition and guided composition, respectively. Informants seemed to be satisfied with the teacher's marks. One of them from the B class said:

Excerpt 16: If you write well you get high marks, but if you put little effort, you fail. One thing that makes me happy with my teacher is that she rewards effort. Another one from the C class, in response to the question: Are you happy with the marks that you get from your teacher in composition writing he said:

Excerpt 17: Yes. She gives us what we deserve. At least she gives no one a zero, even if one goes off topic. Some of the written comments and mark allocation the researcher saw in the students' composition exercise books include: $7 \backslash 20$ Write using given points and write meaningful work. 14\30 Work more on your grammar. 10\30Your writing is not satisfactory. $13 \backslash 30$ Too short for your level. $19 \backslash 30$ Brilliant story, keep it up. 14\30 This is a good story but you failed to make the word have a central part of the story. 17/30 Fairly good work, keep on putting effort.15।30 Good but improve your spellings and grammar. One could see that the teacher's comments addressed composition issues as stipulated in the English language syllabus for instance: composition length, spellings and grammar, handwriting, story focus and following instructions. These aspects are meant for students to improve their composition standard and performance.

\subsection{Feed Forward}

Content analysis and students interviews showed that the composition teacher in question used the information she got from the students' performance for planning purposes. In the Languages and Communication Head of Department's office where the researcher was conducting interviews from, there was a school results chart for English Language which covers public "O" Level results from 2012 to 2016. The fluctuating pass rate ranges from 5\% to $40 \%$. This shows that the pass rate at that school was low and this definitely informed the composition teacher in her composition teaching approach, among other things especially on student improvement as Katrin and Johannes (2013) said.

In relation to general poor performance of student in English Language in general and composition writing in particular, the teacher concentrated on teaching narrative and descriptive compositions putting little effort on the challenging factual and discursive types. This could be seen in the students' composition exercise books and was confirmed by the informants. Of course the informants said that their teacher taught them the following types of composition: factual, narrative, argumentative and the descriptive compositions, a list that tallies with the ZGCE "O" Level English syllabus 2013-2017 
objective number one. However, her concentration was on narrative and descriptive types. One informant knowledgably said:

Excerpt 18: I like the descriptive and the narrative types of compositions. My teacher advised me to concentrate on these. The informants concurred that their teacher recommended every student in class to concentrate on a certain type of composition, each according to his lher academic strength and ability; the majority of the students were recommended to concentrate on the narrative and descriptive type; the informants so said. Teacher's advice to individuals' inclinations is supported by Mee (2016) who argued that a writer's style is a reflection of his or her personality, unique voice and way of approaching the audience and readers. It should be considered for planning purposes.

On the same note, due to the low composition standard of the "O" Level students at the school, the teacher puts a lot of effort on marking students' compositions especially through thorough marking as content analysis and interviews showed. Again, all the informants happily said that their teacher marked their compositions within a short time, an average of a week. Reynolds (2013) also echoed the same sentiments when he said that feedback should be given in a timely manner. One of the informants said:

Excerpt 19: She (teacher) takes about a week to return our marked compositions. This is quite reasonable if one considers that she teaches all the three form four classes with an average of 58 students each. When returning students' exercise books, the informants said the teacher gave detailed oral feedback to the students explaining the students' performance. She explained and justified the low marks and the high marks. She also explained what her expectations were. This is supported by Mahmoodi and Rajabi (2014) and Küçükali (2017) who found, in separate studies in Iran, oral feedback being very effective in enhancing learners writing skills. Catapano (2017) also found the same results.

Informants from the $\mathrm{A}$ and $\mathrm{B}$ class said that the teacher extended her feedback gesture by inviting students to come for consultation during free time. The informants said that they usually go for consultation especially since they started form four as they were already preparing for final examinations at the end of the year. However, the two informants from the $\mathrm{C}$ class said that they never thought of going for consultation during their free time. Teachers should encourage students to consult when necessary. The informants also showed that their composition teacher gave them weekend and holiday composition exercises so that the students get ample practice on composition writing. They said that their teacher tried by all means to mark these compositions.

Content analysis of students' composition exercise books showed that the teacher's Feed Up was associated with corrections. After marking students' compositions and realized that the students had made mistakes that need to be corrected, the teacher asked students to write corrections. This can be part of what Saaris (2016) gave as specific guidance on how to improve. Content analysis and students' interviews showed that the composition teacher was really serious on correction making. One informant said: 
Excerpt 20: The composition teacher constantly and persistently asks us to write corrections. If you want to invite trouble, leave corrections undone. The other informant, when addressing this correction issue, smiled and said:

Excerpt 21: You just have to write the corrections. There are no two ways about it. Our teacher is good at that. Content analysis showed that students wrote corrections. The corrections were usually long, especially in the $\mathrm{C}$ class and were short for higher composition writing performers. The following extract shows long corrections. The strength of the teacher is shown on her marking of all the corrections; an example is shown below.

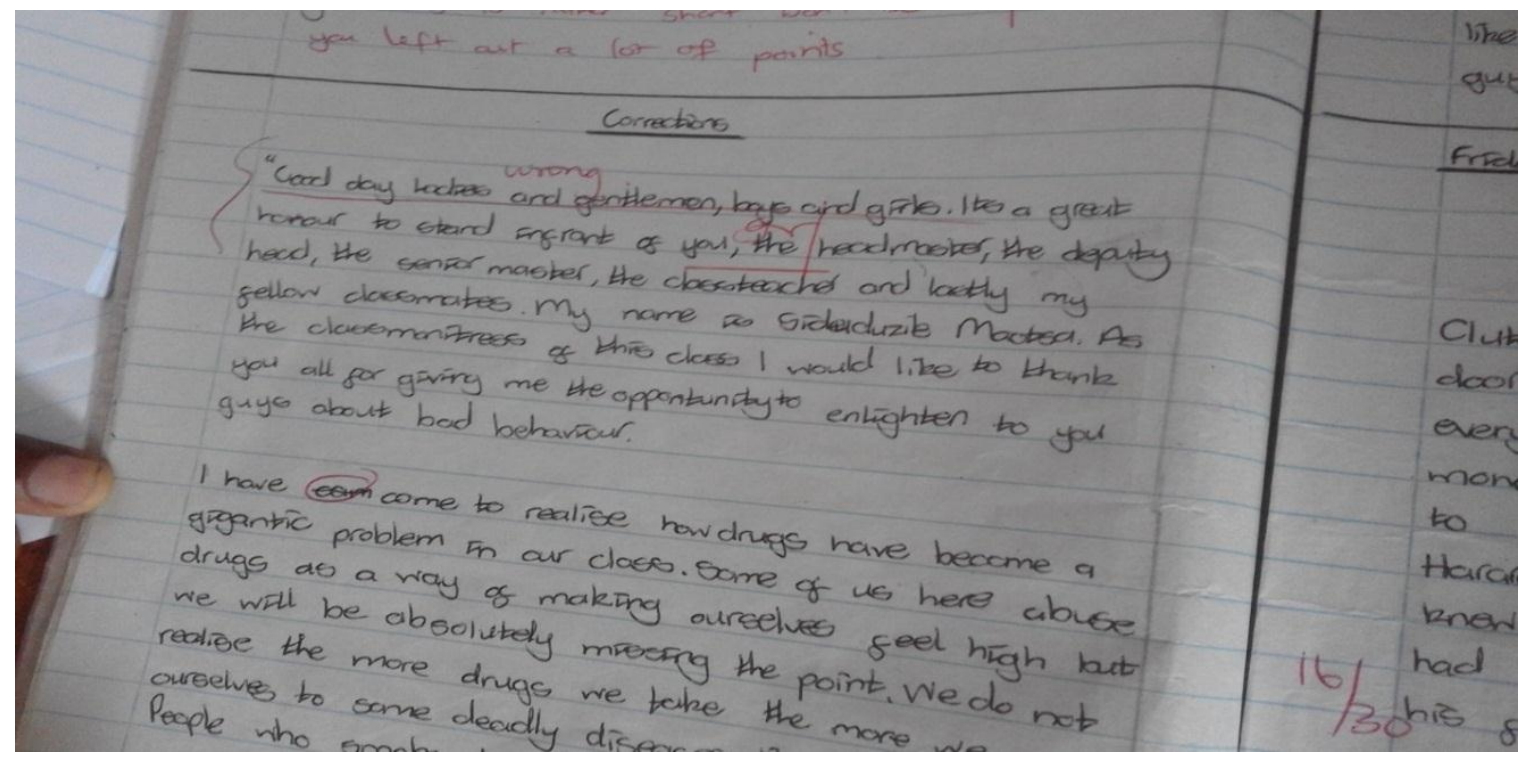

Despite the teacher's effort to make all the students write corrections, some students still did not comply to teacher's instructions as was shown in one composition exercise book whose extract is given next page. The student was supposed to write corrections but did not do so. Helshe only wrote the word corrections and left some space for the corrections; the gap still stood unfilled by the time the study was carried out. The teacher went on to give a written reminder to the student to write correction but to no avail.

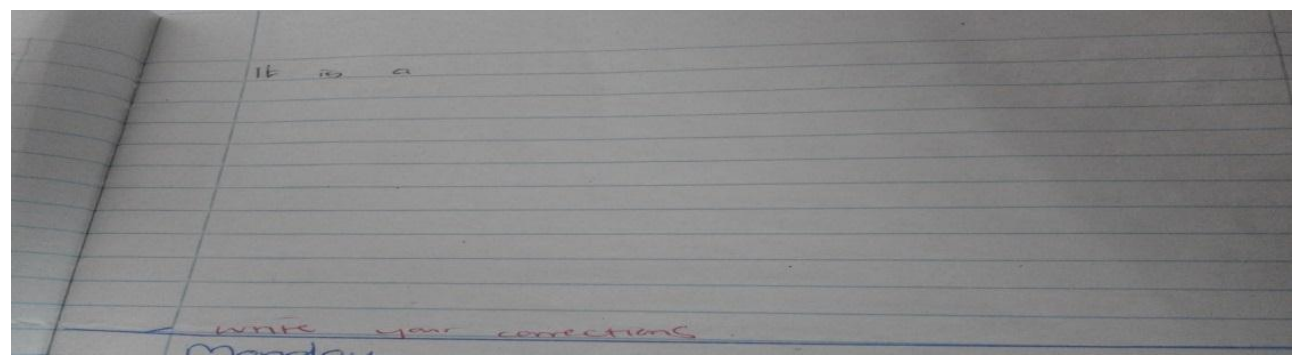

However, such a scenario of unwritten corrections was a rare phenomenon as shown by content analysis. What was usual was written and marked corrections. In the event that a student wrote a new composition 
without writing corrections, the student was asked to write the current as well the previous corrections before writing the composition of the day. These finding are similar to Hattie and Yates' (2014) ideas, in the improved Hattie \& Timperley (2007) Effective Feedback Model; there is emphasis on immediate feedback for novice learners. They also argued that feedback enhances achievement. Thus, the finding of the study and the theory of the study are closely linked. All these teacher's moves were caused by what the teacher realized on students' assessment, hence, Feed Forward.

\section{Conclusion}

The study concluded that, on Feed Up, students got adequate teachers' explanations on composition goals, expectations, instructions and guidelines. The teachers also prepared students to write compositions psychologically. However, although the teacher paid more attention to the $\mathrm{C}$ class that struggles with composition writing than the A and the B classes, the teacher should still emphasize other aspects, for instance, the total composition marks as part of composition expectations. The teacher should also converse with the students so that what the students have understood and have failed to understand is known, hence dialogic feedback which can create and enhances student-teacher relationship and student improvement.

Another problem encountered in the feedback process was that students got insufficient feedback resources from their teachers. Again, not all teachers explained composition mark allocation to the students which negatively affected the students' composition writing. On Feed Back, students got corrected work, meaningful comments and marks from their teachers. Teachers thoroughly marked students' composition books focusing on English "O" Level syllabus requirements. In their marking, teachers used correction codes to indicate errors, however, some students could not understand the codes meanings since they were not given to them. On Feed Forward, composition teachers used the information they got from the students' performance for planning purposes, for instance, due to students' low performance, teachers thoroughly marked students' compositions; they made students' consultation time available, giving weekend and holiday composition exercises as well as encouraging students to write corrections.

\section{Recommendations}

The study recommended that sufficient feedback resources should be supplied to the composition teachers. All composition teachers should explain composition mark allocation to the students whenever they give them composition work. Again, whenever composition teachers use correction codes, elaborations should accompany those codes.

\section{References}

Al-Jarrah, R. S. (2016). A suggested model of corrective feedback provision. Science Direct, 3, 98-107. Retrieved from http://www.sciencedirect.com/science/article/pii/S2215039016300248

Alvira, R. (2016). The impact of oral and written feedback on EFL writers with the use of screencasts.

Profile Issues in Teachers' Professional Development. 18(2), 79-92.

http://dx.doi.org/10.15446/profile.v18n2.53397 
Brown, D. (2012). The written corrective feedback debate: Next steps for classroom teachers and practitioners. TESOL Quarterly, A Journal for Teachers of English to Speakers of Other Languages and of Standard English as a Second Dialect, 46(4), 861-867. Retrieved from http://www.tirfonline.org

Bruno, I., \& Santos, L. (2010). Written comments as a form of feedback. Studies in educational evaluation. ERIC, 36 (3), 111-120. Retrieved from https://eric.ed.gov/?id=EJ916979

Cagla, A. (2016). Contrasting perceptions of students and teachers: Written Corrective Feedback. Journal of Language and Linguistic Studies, 12 (2), 166-182. Retrieved from https://eric.ed.gov/?id=EJ1117969

Carless, D. (2015). Excellence in university assessment: Learning from award-winning practice. Retrieved from https://www.routledge.com/Excellence-in-University-Assessment-Learningfrom-award-winning-practice/Carless/p/book/9781138824553

Catapano, J. (2017). Teaching strategies: The essentials of giving feedback. Retrieved from http://www.teachhub.com/teaching-strategies-essentials-giving-feedback

Chen, S., Nassaji, H., \& Liu, Q. (2016). EFL learners' perceptions and preferences of written corrective feedback: a case study of university students from Mainland China. Asian-Pacific Journal of Second and Foreign Language Education, 1(5). Retrieved from https://sfleducation.springeropen.com/articles/10.1186/s40862-016-0010-y

Chen, Y. (2013). Master's and Doctoral theses on Second Language writing: A survey of the emerging voices in China. (Masters theses). Paper 66. Retrieved from http://scholar orks.gvsu.edu/theses

Crimmins, G., Nash, G., Oprescu, F., Liebergreen, M., Turley, J., Bond, R., \& Dayton, J. (2016). A written, reflective and dialogic strategy for assessment feedback that can enhance student/teacher relationships. Assessment \& Evaluation in Higher Education, 41 (1), 141-153. Retrieved from https://eric.ed.gov/?id=EJ1085838

Dreher, A. (2016). Giving positive and corrective feedback. Retrieved from http://www.mentorleadershipteam.com/articles/giving-positive-and-corrective-feedback

Elliott, V., Baird, J., Hopfenbeck, T., Ingram, J., Thompson, I., Usher, N., . . Zantout, M. (2016). A marked improvement? Retrieved from https://educationendowmentfoundation.org.uk/

Faqeih, H. (2015). Learners' attitudes towards corrective feedback. Procedia - Social and Behavioral Sciences, 192, 664-671. Retrieved from http://www.sciencedirect.com/science/article/pii/S1877042815035727

Ferdouse, F. (2011). Learning from mistakes: Using correction code to improve student's writing skill in English composition class. Retrieved from http://www.banglajol.info/index.php/SJE/article/download/14463/10271

Gwata, D. (2017). Impact of teaching-learning resources in English composition writing at Ordinary Level: The case study of Glen Norah High 1, Queen Elizabeth and Southlea secondary schools in Harare. (Unpublished project). Solusi University.

Han, J., \& Yin, H. (2016). Teacher motivation: Definition, research development and implications for teachers. Teacher education \& development | review article. Retrieved from http://dx.doi.org/10.1080/2331186X.2016.1217819

Hattie, J., \& Timperly, H. (2007). The power of feedback. Retrieved from Growthmindseteaz.org

Hattie, J. A. C., \& Yates, G.C.R. (2014). Using feedback to promote learning. Retrieved from http://teachpsych.org/ebooks/asle2014/

http://scholarship.shu.edu/cgi/viewcontent.cgi?article

Kang, E., \& Han, Z. (2015).The Efficacy of Written Corrective Feedback in Improving L2 Written Accuracy: A Meta-Analysis. The Modern Language Journal , 99 (1). Retrieved from http://onlinelibrary.wiley.com/doi/10.1111/modl.12189/pdf

Katrin, H., \& Johannes, H. ( .(2013Understanding and using feedback: A review of empirical studies concerning feedback from external evaluations to teachers. Educational Research Review, 9, 174-190. https://eric.ed.gov/?id=EJ999457 
Karim, K., \& Nassaji, H. (2012). Corrective feedback in second language writing. Retrieved from https://www.tru.cal_.../Khaled_Karim_and_Hossein_Nassaji_-_

Lee, I. (2011). Working smarter, not working harder: Revisiting teacher feedback in the L2 writing classroom. Canadian Modern Language Review, 67 (3), 377-399. Retrieved from http://eric.ed.gov

McCarthy, J. (2016). Timely Feedback: Now or Never. Retrieved from https://www.edutopia.org/blog/timely-feedback-now-or-never-john-mccarthy

Mee, S. H. (2016). Four different types of writing styles: Expository, descriptive, persuasive, and narrative. Retrieved from https://letterpile.com/writing/Four-Types-of-Writing

Mukeredzi, T. G. (2016). The nature of professional learning needs of rural Secondary school teachers. Voices of professionally unqualified teachers in rural Zimbabwe. Sage Journals. 6 (2).

Retrieved from htp://journals.sagepub.com/doi/full/10.1177/2158244016643142

Nabiryo, N. R. (2011). Factors influencing students' writing skills in English: A case study of selected secondary schools in Rubaga Division, Kampala District. Retrieved from http://hdl.handle.net/10570/2621

Nielsen, D. (2015). The impact of formative feedback on student motivation to write in eighth grade English courses. (Thesis). Paper 440. Retrieved from http://cornerstone.lib.mnsu.edu

Oskoz, A., \& Elola, I. (2017). Writing with 21 st century social tools in the L2 classroom: New literacies, genres, and writing practices. Journal of Second Language Writing, 36, 52-60. Retrieved from https://www.researchgate.net/publication/311669829_ESL_Learners'_Writing_Skills_Problems _Factors_and_Suggestions

Oyedele, V., \& Chikwature, W. (2016). English composition writing skills at Ordinary Level and its effect on students' performance in three day secondary schools in Mutare District. European Journal of English Language, Linguistics and Literature, 3 (1). Retrieved from www.idpublications.org

Parr, J. M., \& Timperley, H. S. (2010). Feedback to writing, assessment for teaching and learning and student progress. ERIC, 15 (2), 68-85. Retrieved from https://eric.ed.gov/?id=EJ890803

Peary, A., \& Hunley, T. C. (2015). Creative writing and process pedagogy. Retrieved from https://muse.jhu.edu/chapter/1586899

Reynolds, L. (2013). 20 ways to provide effective feedback for learning. Retrieved fromhttps://www.teachthought.com/technology/20-ways-to-provide-effective-feedback-forlearning/

Saaris, N. (2016)._Effective feedback for deeper learning. Retrieved from http://www.activelylearn.com/

Shintani, E. 2014). Corrective feedback. https://outspokenela.files.wordpress.com

Three-mob.com. (2013). Zimbabwe 'O' Level results: Pass rate down. Retrieved from http://www.3mob.com/featured/zimbabwe-o-level-results-pass-rate/\#.WgQKrXZLfIU

Wiggins, G. (2014). What feedback is and is not. Retrieved from https://grantwiggins.wordpress.com/2014/04/15/what-feedback-is-and-isnt/

Y1Feedback (2016). Technology-enabled feedback in the first year: A synthesis of the literature. Retrieved from https://www.teachingandlearning.ie/wp-content/uploads/2016/10/

ZGCE “O” Level English Syllabus (1122) - ZIMSEC. June/November 2013 - 2017 retrieved from http://www.zimsec.co.zw/O_SYLLABUS/O_ENGLISH.pdf 